\title{
GEOCHEMICALLY HOMOGENEOUS TUFFS HOST THE POTENTIAL NUCLEAR WASTE REPOSITORY, YUCCA MOUNTAIN, NEVADA
}

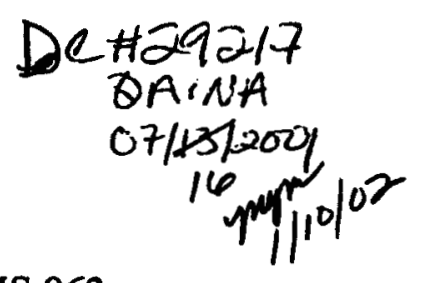

Zell E. Peterman, peterman@usgs.gov, 303-236-7883, U.S. Geological Survey, MS 963, Box 25046 Denver Federal Center, Denver CO 80225

Key Words: Yucca Mountain, nuclear waste, geochemistry, tuff,

\section{ABSTRACT}

In evaluating a geological environment for the disposition of nuclear waste, the composition of the host rock is an important parameter in characterizing the natural system and its role as a barrier to migration of radionuclides. Emplacement drifts in a potential nuclear waste repository at Yucca Mountain, Nevada, would be constructed in the lower phenocryst-poor rhyolitic member ( $-300 \mathrm{~m}$ thick) of the Topopah Spring Tuff, a felsic pyroclastic ash flow. The rhyolitic member, composed largely of microcrystalline quartz and alkali feldspar, contains localized secondary minerals including vapor-phase silica polymorphs and feldspar typically lining lithophysal cavities, and low-temperature calcite and opal in cavities and fractures. Chemical analyses of Topopah Spring Tuff samples from outcrops and from core obtained by surface-based drilling have shown that the phenocryst-poor rhyolite member at Yucca Mountain is remarkably uniform in composition both vertically and laterally. To verify this geochemical homogeneity in samples collected directly from the repository block where emplacement drifts would be constructed, major and trace elements were analyzed for core samples obtained from 20 systematically spaced drill holes in a drift constructed across the repository block. Means and standard deviations of selected oxides and elements in weight percent indicate geochemical uniformity among these samples: $\mathrm{SiO}_{2}$, $76.29 \pm 0.32 ; \mathrm{Al}_{2} \mathrm{O}_{3}, 12.55 \pm 0.14 ; \mathrm{FeO}, 0.13 \pm 0.05 ; \mathrm{Fe}_{2} \mathrm{O}_{3}, 0.97 \pm 0.07 ; \mathrm{MgO}, 0.12 \pm 0.02$ 
$\mathrm{CaO}, 0.50 \pm 0.03 ; \mathrm{Na}_{2} \mathrm{O}, 3.52 \pm 0.11 ; \mathrm{K}_{2} \mathrm{O}, 4.83 \pm 0.06 ; \mathrm{TiO}_{2}, 0.109 \pm 0.004 ; \mathrm{ZrO}_{2}$ $0.016 \pm 0.001 ; \mathrm{MnO}, 0.068 \pm 0.008 ; \mathrm{Cl}, 0.017 \pm 0.004 ; \mathrm{F}, 0.038 \pm 0.008 ;$ and $\mathrm{CO}_{2}$, $0.011 \pm 0.003$. Means and standard deviations of selected trace elements, in micrograms per gram, also indicate small compositional variability: $\mathrm{Ba}, 51 \pm 12$; $\mathrm{Cs}, 4.2 \pm 0.3 ; \mathrm{Li}$, $25 \pm 9 ; \mathrm{Pb}, 27 \pm 1 ; \mathrm{Rb}, 186 \pm 9 ; \mathrm{Sr}, 27 \pm 3 ; \mathrm{Th}, 26 \pm 1 ; \mathrm{U}, 3.9 \pm 0.3$. Geochemical uniformity of the host rock is a positive attribute in that it provides a uniform near-field chemical environment for the potential repository. 